\title{
The Krnka-Hebler Bullet
}

\section{Captain F. L. Nathan R.A.}

To cite this article: Captain F. L. Nathan R.A. (1894) The Krnka-Hebler Bullet, Royal United Services Institution. Journal, 38:192, 172-174, DOI: 10.1080/03071849409416981

To link to this article: http://dx.doi.org/10.1080/03071849409416981

\section{曲 Published online: 11 Sep 2009.}

Submit your article to this journal $\pi$

Џll Article views: 7

Q View related articles $₫$ 


\title{
T'HE KRNKA-HEBLER BULLET.
}

\author{
By Captnin F. L. Natmax, R.A.
}

Oxe of the latest developments of the small-bore magazine rifle. question, is the tubalar bullet, invented by Charles Krnka, of Pragne, and William Hebler, of Kiissnacht, and recently patented in this country. The inventors point out that one of the chief canses which detrimentally influence the relocity of a projectile through the air, is the resistance of the atmosphere, which arises from two causes, vi\%: :

1. The condensation or compression of the air strata immediately in front of the projectile; and

2. The formation of a vacuurn immediately behind the projectile.

In carying out their inrention, which is mainly designed to diminish, as far as possible, the resistance under both of the above heads, they make the projectile pointed at both ends, and with an air channel or passage through it.

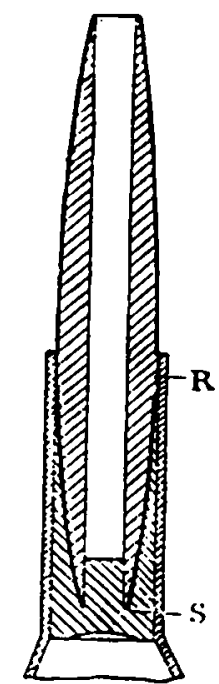

Fig. 1.

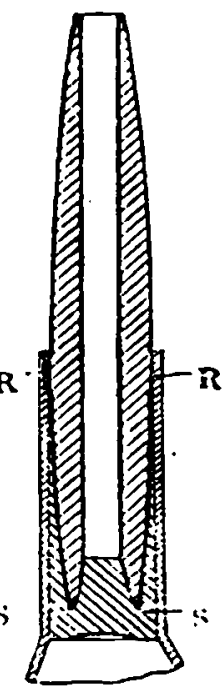

Fig. 2.

The sketches represent two forms of hollow bullet for smallbore rifles. In Fig. 1 the projectile has a steel envelope only; in Fig. 2 the hollow also is lined internally with a tube of steel, which gives to $5 \cdot \mathrm{mm}$. (0-127-in.) bullets the neecssars rigidity. To impart 
yotr.tion, the bullets are made with a projecting ring (R) where they eviter the neck of the cartridge case. $A$ sabot $(S)$ of paper, or similar - material, is fitted to the baso of the ballet to prevent it oscillating in the borc, and also to prerent, tho escape of gas ; this sabot frees itself from the projectile as the latter leares the gun. Instead of being male of lead with steel envelope, the bullet can be made entirely of steel or other metal ; in the case of steel, a ring or band of some softer metal being attached to the bullet.

Professor IIeller, in an article recently published in the "Allgemeine Schweitzerischo Militär-Zeitung," and which has been reproduced in several foreign service periodicals, states that the first experiments with tubular bullets date from 1874, but for a long time ther met with no success, as the soft lead bullets of those days were distorted in tho barrel. With the introduction, howerer, of the modern smallcalibre bullet with its stcel or nickel alloy eurelope, the difficulty disappeared, and as the result of experiments with a rariety of patterns, that jost described. was decided upon as giving the best results. The best diameter for the central cliannel was found to be about two-fifths of the actual calibre of the ballet. He determined, from experiments with this bullet in the German 7.9-mm. (0.311-in.) rifle, and in his own 5 -mm. $(0 \cdot 197-$ in.) rifle, that for: all relocities between 100 and $1,000 \mathrm{~m}$. (328 to 3,280 . f.s.) the resistance of the air was nearly proportional to the square of the relocity:

He points out that the penetration is diminished, but the trajectory is flatter, particularly at short and medium ranges, and the pressnres and recoil are less; also, the ammunition being lighter, the soldici can cary more cartridges.

The only alterations to existing rifles which the use of these bullets entails are, the regraduation of the sights, and a slight increase in the length of the small cylinder of the chamber, owing to the extra length of the neck of the cartridge case, to enable it to grip the projecting ring of the bullet.

In order to compare the decrease in the resistance of the air, this resistance with the German rifle, Pattern 188E. may be represented by $1,000,541,216$, and 89 respectirels, necording to which of tho following bullets are used, riz.:-

1. The serrice bullet.

2. The service bullet with flat base and improred ogival point.

3. The service bullet with ogival base the same as the point.

4. The tabular bullet with ogiral base and point.

With the 5-mm. (0.197-in.) rifle, the muzzle relocity being $750 \mathrm{~m}$. $(2,460$ f.s. $)$, these figures becoune $1,000,463,285$, and 63 .

The increase in the flatness of the trajectory will be seen from the following figures :-

$\Delta t 1,000 \mathrm{~m}$. (1,093 Jds.), with the 11-mw. (0.433-in.) Mauser rifle, Pattern 1871, the danger zone is $20 \mathrm{~m}$. (21.57 Jds.). With the 7.9-rum. (0.31l-in.). Pattern 185S, rifle and service bullet, it is $42 \mathrm{~m}$. ( $46 \mathrm{yds}$ ); with the same rifle and tubalar bullet, it is $218 \mathrm{~m}$. (238.4 $\left.\mathrm{yds}^{\circ}\right)$; and finally, with the $5 \cdot \mathrm{mm}$. (0-197-in.) rifle and tubular 
bullet, it is $400 \mathrm{~m}$. (437.4 jds.), or 20 times that of the Patter:s 1871 rifle.

The following are some of the more important results giren $b_{\ldots}$ Professor Ilebler, of the experiments carricd out by him :-

German Rifle, Pattern 1888.-T'ho muzzlo velocity obtained was $787 \mathrm{~m}$. (2,5s2 f.s.), whilst that of the servico bullet with the sanc charge ( $2.75 \mathrm{grm}$. (42.43 gr.) smokeless powder) is $640 \mathrm{~m}$. (2,100 f.s.).; 182 cartridges weigh 4 kilos. ( 141 oz.), which is tho weight of 145 scrrice cartridges. Tho maximum pressure was 1,550 atmos. ( 10.2 tons per sq. in.); with the service bullet, it is 3,000 atmos. (19.7 tons per sq. in.). The penetration into pine was: at the muzzle, $117 \mathrm{~cm}$. (46 in.); at $1,000 \mathrm{~m}$. (1,093.6 jds.), $75 \mathrm{~cm}$. (29.53 in.); at $2,5000 \mathrm{~m}$. (2,734 yds.), $30 \mathrm{~cm}$. (7.8 in.).

Hebler 5-mm. (0.197-in.) Rijle.-The nuzzle velocity was $1,050 \mathrm{~m}$. (3,445 f.s.), ( $797 \mathrm{~m}$. (2,615 f.s.) with tho ordinary bullet), with a charge of $1.6 .1 \mathrm{grm}$. (25.3 gr.) of the Cologno Rottwcil smokeless powder, normal charge being 15 grm. (23.15 gr.); 321 cartridges weigh 4 kilos. (141 oz.), which is tho weight of 276 cartridges with the ordinary bullet. The maximum pressuro was 2,400 atmos. (15.75 tons per sq. in.); with the ordinary bullet, it is 3,633 atmos. (23.85 tons per $8 q$. in.). The penetration into pine was: at thes muzzle, $204 \mathrm{~cm}$. $(80.32$ in.); at $1,000 \mathrm{~m}$. (1093.6 yds.), $143 \mathrm{~cm}$. (56.3 iu.); at $2,500 \mathrm{~m}$. (2,734 yds.), $84 \mathrm{~cm}$. (33 in.). The effective range was $5,234 \mathrm{~m}$. $(5,724 \mathrm{yds}$.); the total range was $9,172 \mathrm{~m}$. $(10,030 \mathrm{gds}$.$) .$ 